\title{
THE ORTHOGRAPHICAL KANONS OF NICETAS OF HERACLEA*
}

In the study of the philological tools, such as grammars and lexica, which the medieval authors had at their disposal, a mass of work still lies ahead, including basic groundwork, as for example the edition of unpublished and, therefore, little known texts. This is the case with two poems of Nicetas of Heraclea, known as his Orthographical Kanons due to the fact that they are written in the form of a liturgical kanon. I intend to publish an edition of the Kanons and what I am offering here is some preliminary remarks on various aspects of these works.

Nicetas is a well known figure, although the course of his life has not yet been fully established. During the course of the twentieth century scholars made various suggestions, summaries of which have recently appeared (in fact, thrice in the nineties). ${ }^{1}$ Therefore, I need only point out the following. It is an established fact by now that Nicetas was normally

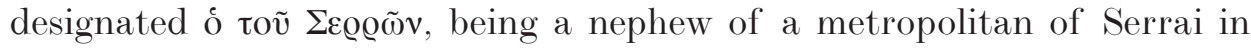
Macedonia. He appears to have remained a teacher for most of his life, starting as proximos at the school of Chalkoprateia and becoming a teacher of the Patriarchal school, probably ending with the ultimate post there, that of teacher of the Gospel. He was a deacon of St Sophia in Constantinople and later metropolitan of Heraclea in Thrace, in which capacity he

* This article reproduces a paper delivered at the Conference "The Origins of European Scholarship", which was organized by the Department of Classical Studies and Philosophy of the University of Cyprus (6-9 April 2000). The footnotes have been updated; ef. esp. n. 15.

${ }^{1}$ See A. Kazhdan et al. (edd.), The Oxford Dictionary of Byzantium III. New York-Oxford 1991, 1481; P. van Deun, Les Diversa Capita du pseudo-Maxime (CPG 7715) et la chaîne de Nicétas d'Héraclée sur l'Évangile de Matthieu (CPG C 113). JÖB 45 (1995)

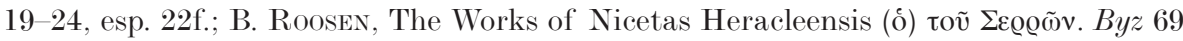
(1999) 119-144, esp. 138-140. See also the older, but still important work on Nicetas by J. Sickenberger, Die Lukaskatene des Niketas von Herakleia ( $T U$ 7/4). Leipzig 1902, to which various corrections have been made by subsequent scholars, as well as $\mathrm{R}$. Browning, The Patriarchal School at Constantinople in the Twelfth Century. Byz 33 (1963) 11-40, esp. 15-17, and the works by Darrouzès mentioned below, nn. 6 and 7 . 
was involved in the dogmatic controversy concerning Eustratios of Nicaea. The date at which he became a metropolitan was set by J. Darrouzès at 1117 on the basis, on the one hand, of Nicetas' discourse against Eustratios of Nicaea, which refers to Nicetas by his new title and can be safely dated to shortly after 27 April 1117, and on the other hand, of the evidence of the oldest manuscript containing Nicetas' catena on Luke, Vaticanus gr. 1611, begun on 11 June 1116 and finished after 19 May 1117, the title of which refers to Nicetas as a deacon and teacher. This date was repeated in two recent accounts of Nicetas' life, which at the same time downplayed (though in different ways) $^{2}$ the analysis of J. Irigoin that proved the South Italian instead of the frequently assumed Constantinopolitan origin of the manuscript in question. The implication of this change of location was fully recognized by Irigoin, namely that this codex cannot serve as terminus post quem for the ascent of Nicetas to the metropolitan throne. ${ }^{3}$ Therefore, one should only go so far as to state that in April 1117 Nicetas was already metropolitan of Heraclea. ${ }^{4}$ Nothing is known of the later period of his life. This reversal of facts has a direct impact on the possible date of Nicetas' birth, over which confusion prevails, ca. 1050 and 1060 having replaced the once accepted date of 1030 . In fact, if Nicetas had actually become metropolitan in 1117 and given that he was a teacher of St Sophia by $1088 / 9,{ }^{5}$ he should have been born around 1060, as maintained by Roosen following Darrouzès; otherwise, he would have been over 60 years of age and too old for the post. ${ }^{6}$ Since, however, 1117 is no longer an obstacle, an earlier date of birth is not out of the question and the suggestion of ca. 1050 by Kazhdan (and, originally, van Deun) may well be preferred.

Nicetas was a prolific author. He is mostly known for his catenae on the Gospels of Matthew, Luke, and John and a commentary on Gregory of Nazianzus. He also wrote several grammatical poems, the product of his teaching activity in Constantinople. However, the exact extent of his

\footnotetext{
2 See van Deun, Les Diversa Capita 22f.; Roosen, Works 140 n. 124.

${ }^{3}$ See his Pour un bon usage des abréviations: le cas du Vaticanus graecus 1611 et du Barocci 50. Script 48 (1994) 3-17, esp. 9.

${ }^{4}$ As do Browning, Patriarchal School 17; P. Gautier, Théophylacte d'Achrida. Lettres (CFHB 16/2). Thessalonica 1986, 95; and KAZHDAN, ODB III, 1481.

${ }_{5}^{5}$ On the latter point see below on the dating of the Kanons.

${ }^{6}$ See J. Darrouzès, Documents inédits d'ecclésiologie byzantine (Archives de l'Orient chrétien 10). Paris 1966, 54-57, esp. 57; Roosen, Works 139 n. 118; cf. P. van Deun, Nicétas d'Héraclée, Commentaire sur l'Évangile de S. Matthieu: Édition critique du Chapitre 4. Byz 71 (2001) 517-551, esp. 517, who accepts this dating, while in his Les Diversa Capita 22, he had opted for ca. 1050.
} 
oeuvre remains relatively uncertain. The most comprehensive list of Nicetas' works, both secular and ecclesiastical, was compiled by Roosen in his recent article already mentioned. This list certainly fills a vacuum giving both Nicetas' published and unpublished authentic works as well as works the authenticity of which is either to be proven or has been refuted; however, without an inspection of the manuscripts the list has a provisional character, as the author himself states. ${ }^{7}$ A definitive list of all of Nicetas' works will not be possible until all of the unedited works are published and arguments put forward regarding the authenticity of certain works attributed to him.

As far as scholarly work on the Kanons is concerned, the first to have dealt with them was Leopold Cohn in 1886 in the first Epimetrum to his study and edition of Nicetas' verses on mainly geographical names, which in the manuscripts are usually found together with the Kanons. ${ }^{8}$ Without an accompanying study, Cohn offered an edition of the first two odes (odes

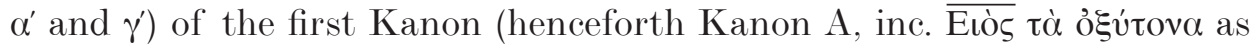

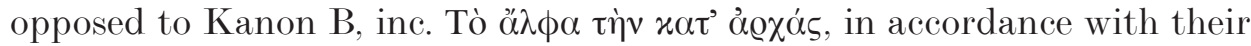
order in most of the manuscripts and their so far standard designation which was assigned to them by Cohn). ${ }^{9}$ This edition was based on three codices, Dresdensis Da 37 (14th cent. med.), Parisinus gr. 2558 (15th cent. in.) and Vindobonensis theol. gr. 203 (14th cent.). In the apparatus the editor identified the model of the Kanon as the famous eighth-century kanon on the Dormition of the Virgin Mary by John of Damascus (in $\tilde{\eta} \chi \chi \mathrm{c}$ $\left.\delta^{\prime}\right) .{ }^{10} \mathrm{He}$ also briefly noted that there are certain unspecified discrepancies in the fourth and the last verses of the troparia of the first ode. This partial edition is inadequate for reasons that will be explained below.

${ }^{7}$ It should be noted that no. 1.2.1. is not an independent theotokion, but belongs to Nicetas' first orthographical Kanon (no. 1.1.3.1.), as DARrouzès, to whom Roosen, Works 128 refers, clearly stated, see his Notes de littérature et de critique. RÉB 18

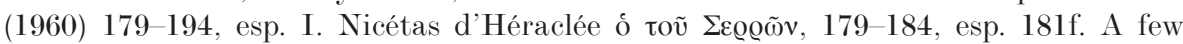
months later and independently of Roosen, Nicetas' grammatical poems were dealt with by J. Schneider: La poésie didactique à Byzance: Nicétas d'Héraclée. Bulletin de l'Association Guillaume Budé 58/4 (1999) 388-423; based on the testimony of three manuscripts he adds two more unedited grammatical poems in hymnic form, see esp. pp. 393 and 417 n. 115.

${ }^{8}$ See his Nicetae Serrarum episcopi Rhythmi de marium fluviorum lacuum montium urbium gentium lapidum nominibus. Neue Jahrbücher für Philologie und Pädagogik 133 (1886) 647-666, esp. 661-664.

9 "Canon prior" and "canon alter", see ibid., 661; only the critical edition of the Kanons will definitively decide on the correctness or not of this designation.

10 See the edition in W. Christ - M. Paranikas, Anthologia graeca carminum christianorum. Leipzig 1871; repr. Hildesheim 1963, 229-232. 
Two years later a brief and for a long time the only study of the Kanons in question appeared as part of P. Egenolff's classic study of the Byzantine orthographical texts, the edition of which he was preparing for the planned fifth volume of the Grammatici Graeci. He pointed out the practical purposes served by the kanon form of the poems and listed, based on the information of Cohn, several codices containing the Kanons. ${ }^{11}$

In the following decades brief treatments of or references to the Kanons appeared as part of accounts of Byzantine orthographical literature by $\mathrm{K}$. Krumbacher, C. Wendel, and H. Hunger, and of Byzantine parahymnography by K. Mitsakis. ${ }^{12}$ Moreover, in so far as they provide evidence for the person of the author, the colophons of the two Kanons were the focus of studies by J. Darrouzès ${ }^{13}$ and Anna Maria Guglielmino; the latter also argued in favour of a collection of Nicetas' grammatical works which ended with Kanon A. ${ }^{14}$

Finally, without knowledge of Guglielmino's article, Jean Schneider came to a similar conclusion in his recent article on Nicetas' grammatical poetry, suggesting that the two Kanons formed an indispensable part of a

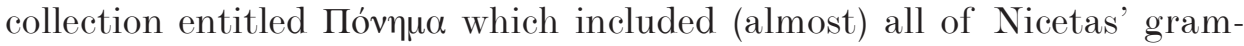
matical poems in various hymnic forms. He also made important observations with regard to the literary nuance of the language of the Kanons, applied by the author in place of the traditional dry grammatical terms, as well as to the audience of these poems and their manuscript tradition. $^{15}$

${ }^{11}$ See his Die orthographischen Stücke der byzantinischen Litteratur (Wissenschaftliche Beilage zu dem Programm des gr. Gymnasiums Heidelberg für das Schuljahr 1887/88). Leipzig 1888, esp. 27-29.

${ }^{12}$ K. Krumbacher, Geschichte der byzantinischen Litteratur von Justinian bis zum Ende des oströmischen Reiches (527-1453). Munich ${ }^{2} 1897,587 f$; C. Wendel, Orthographie. RE 18/2 (1942) 1452f.; H. Hunger, Die hochsprachliche profane Literatur der Byzantiner II (Byzantinisches Handbuch im Rahmen des Handbuchs der Altertumswissen-

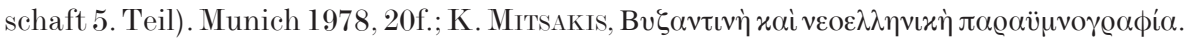

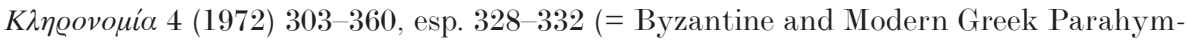
nography, in: D. Conomos [ed.], Studies in Eastern Chant V. Crestwood 1990, 9-76, esp. $38-44)$.

${ }_{13}$ Notes 181-183.

${ }^{14}$ Un maestro di grammatica a Bisanzio nell'XI secolo e l'epitafio per Niceta di Michele Psello. Siculorum Gymnasium 27 (1974) 421-463, esp. 435-439 (note that the main argument of this article, namely the identification of Nicetas of Heraclea with the grammatikos Nicetas, on whom Psellos wrote a funeral oration, is at fault).

15 Schneider, La poésie didactique. This article, published in December 1999, was brought to my attention during the Conference at which this paper was delivered, in early April 2000 , by Prof. A. Wouters, whom I cordially thank. Since that article and the present 
The Kanons can possibly be dated on internal criteria. As Darrouzès showed, the first troparion of the colophon of Kanon A is the work of Nicetas, who on his own testimony composed the Kanon while still proximos at the Chalkoprateia. On the other hand, another troparion of this colophon as well as most of the colophon of Kanon B are the work of a copyist (see below), who worked while Nicetas had already become a metropolitan. Since Nicetas' original colophon can be interpreted as implying that his uncle Stephanos, the metropolitan of Serrai, who was still alive in 1071, was already dead when the Kanons were composed, we possibly have both an approximate date for Nicetas' activity as proximos and a terminus post quem for the composition of the Kanons. ${ }^{16}$ The terminus ante quem is provided by two letters (nos. 7 and 70) of Theophylact of Ochrid addressed to the didaskalos Nicetas, that is Nicetas as teacher of the Great Church. The earliest of these letters (no. 7) should probably be dated to 1088/9, shortly after Theophylact went to Ochrid. ${ }^{17}$

The basic structure of both Kanons is typical for the genre. Each consists of eight songs or odes numbered $\alpha^{\prime}$ and $\gamma^{\prime}$ to $\theta^{\prime}$, since the second ode with its originally mournful character was, as usual, left out. Each ode consists in turn of a varying number of stanzas or troparia following the musical and metrical pattern of the heirmos, the model stanza of the ode. The metre is based on the number of syllables and the placement of the accents of each verse, which correspond to those of the respective verse of its heirmos. In accordance with a large part of the tradition, Nicetas did not compose the melodies himself, but followed well-known musical pat-

paper, which had already been announced with an accompanying abstract in mid-1999 in the circular of the Conference and has a considerably different viewpoint, were written independently of each other, I have not incorporated Schneider's remarks into the main text (except for a couple of explicitly mentioned references), but referred to him in the footnotes whenever needed. The same holds true for another work by Schneider which was published in the meantime and in which occasional passing references to Nicetas' Kanons are also found, see his Les traités orthographiques grecs antiques et byzantins (Corpus Christianorum. Lingua Patrum 3). Turnhout 1999.

${ }^{16}$ Darrouzìs, Notes 183. On the other hand, see ID., Documents 57, following whom Roosen, Works 139f. dates Nicetas' activity as proximos and the writing of his grammatical works between 1080 and 1088/9; but the former date is only based on the inferences drawn from the acceptance of 1117 as the year of Nicetas' enthronement, namely that if Nicetas had been born ca. 1060, he probably started teaching around the age of 20; however, as mentioned above, the date of Nicetas' birth could be earlier by a decade.

${ }^{17}$ See Gautier, Théophylacte 95; Roosen, Works 129, 139f.; a third letter, no. 91, was probably also addressed to Nicetas, see Gautier, Théophylacte 96; Roosen, Works 129. 
terns of older kanons. ${ }^{18}$ In fact, he borrowed the musical and metrical pattern not only of the first but also of the second Kanon from John of Damascus, the model of Kanon B being John's Easter Kanon included in

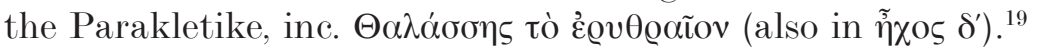

As far as the length of the Kanons is concerned, certain conclusions can be drawn based on the study of all surviving manuscripts. Kanon A consists of 152 troparia in total, their number in each ode ranging from 10 to 34. The last three troparia form the poem's colophon. However, one of

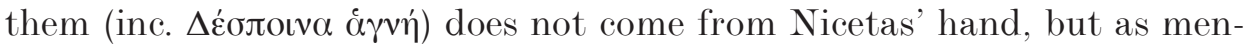
tioned above, was added by a copyist named Stephanos, ${ }^{20}$ who was careful enough to successfully follow the heirmos of the original. No internal evidence points to the authorship of another troparion of the colophon

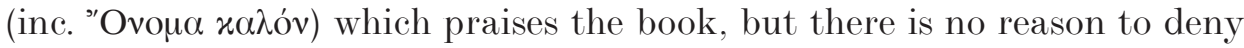
its attribution to Nicetas. In fact, in some manuscripts this troparion precedes the one by the copyist. ${ }^{21}$ Kanon $\mathrm{B}$ consists of 178 troparia. It is noteworthy that in a considerable number of manuscripts, a group of five troparia are absent from the sixth ode. The length of each ode varies from 9 to 30 troparia, while the last four form the colophon. Of the latter, however, only the first, which is again a praise of the work, probably belongs to Nicetas, whereas the last three were written by the copyist Stephanos, who included his name in the last two. ${ }^{22}$ As was the case with Kanon A, Stephanos followed carefully the respective heirmos. The extraneous character of the additions by the copyist is revealed by the fact that the

18 On the kanon, which allowed a variety of melodies equal to the number of heirmoi and had become increasingly popular already in the eighth century, see the classic study by E. Wellesz, A History of Byzantine Music and Hymnography. Oxford ${ }^{2} 1961,198-$ 228.

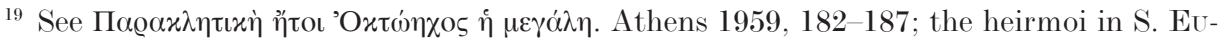

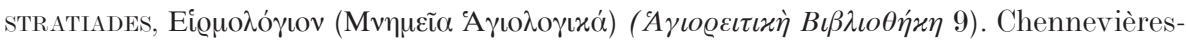
sur-Marne 1932, 94 under the name of John the Monk, as is also the case with the heirmoi of Kanon A, see ibid., 99-100. However, John the Monk cannot always be identified with John of Damascus, see Weltesz, A History of Byzantine Music 237. On the identification of the model of Kanon B see also Schneider, La poésie didactique 394 and n. 40 (John the Monk).

${ }^{20}$ In some manuscripts other names appear, that is Hyakinthos, Mark, and Constantine; see Darrouzès, Notes 182; also Guglielmino, Un maestro 437 and n. 83, and Schneider, La poésie didactique 394-395. The evaluation, however, of the manuscript tradition has led me to the conclusion that these names are variations of the original name, that is Stephanos, by the respective scribe.

${ }^{21}$ E.g. in Vaticanus gr. 868.

${ }^{22}$ The name again differs in some manuscripts: Hyakinthos, John, Sisoes, Mark; cf. above n. 20. 
troparia that are certainly his in both Kanons are omitted in part of the manuscript tradition. ${ }^{23}$

So far there has been no detailed description of the contents or structure of the Kanons apart from some general remarks, something only to be expected for a practically unedited text. Moreover, the publication of only two odes proved confusing in this respect, leading Wendel and Hunger to state that their structure is not clear at all. ${ }^{24}$ Taking both poems into consideration, the following observations can be made (it goes without saying that a definitive description will have to wait until we possess a critical edition). ${ }^{25}$

As regards the subject of the Kanons, according to the (original) colophon of Kanon A, its contents are defined as antistoicha and rules (A9.29

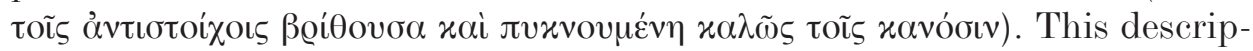
tion also applies to Kanon B, since both Kanons deal with the antistoicha, namely the four series of corresponding vowels in the iotacistic and related pronunciation, which had already prevailed for a long time: $\alpha \iota / \varepsilon, \iota / \eta / \varepsilon$, $\mathrm{o} / \omega$, and $v / \mathrm{oc}$. It is characteristic that in part of the manuscript tradition

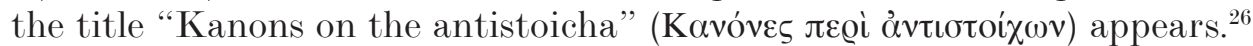
The purpose of the examination is to ascertain whether certain words or parts thereof are spelled with one or the other of the single vowels or "diphthongs" of the same pronunciation. Each of the cases dealt with is illustrated by several examples, for some of which an explicatio is provided. There is no apparent system as to when such "lexical glosses" ${ }^{27}$ appear and

${ }^{23}$ E.g. in the thirteenth-century Vindobonensis phil. gr. 323. On the publications of the colophons as well as the scribal additions to them see SchneIder, La poésie didactique 393-395 nn. 37-39, 41, 42, and 44, who publishes Nicetas' colophons too, see ibid., 41lf.; to these add the publication by GugLIELMINo of the original and scribal colophons of both Kanons in their entirety, see Un maestro 435-438. In all these publications the troparia appear in prose form.

${ }^{24}$ Wendel, Orthographie 1453; Hunger, Literatur II, 20.

${ }^{25}$ In the following references are made to Cohn's edition (see above n. 8, pp. 662-664) for the first two odes of Kanon A, and to cod. Vindobonensis phil. gr. 154 (14th cent.) for the rest of the poems. The Vindob. belongs to a group of manuscripts that preserve the fullest version of the Kanons with the exception of the aforementioned five troparia in B6 (Schneider's references are to cod. Parisinus gr. 2558, see La poésie didactique 404; this manuscript preserves the five troparia in B6, but omits B3.5 and presents an occasionally deviating order of the rest, which is peculiar to it).

${ }^{26}$ E.g. in cod. Vindobonensis phil. gr. 323, f. 5 r with reference to both Kanons, and cod. Laurentianus Plut. 57.26, f. 92r with reference to Kanon B.

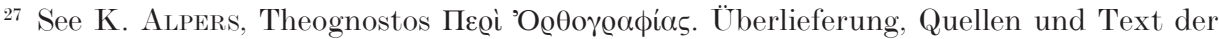
Kanones 1-84. Hamburg 1964, 27. 
it seems plausible that the presence of explicationes depends not so much on the degree of difficulty of a given word, since certain difficult words are left unexplained, but mainly on the ad hoc metrical needs in order to fill a verse with words of correct accents. Etymologies are sometimes included, usually so as to group certain words around their root.

The principle behind the structure of these works is first and foremost alphabetical. The Kanons can be divided into groups of troparia encompassing whole odes or parts thereof, each group dealing with a letter of the alphabet. Such an alphabetical order was not Nicetas' invention. There is, however, a peculiarity pertaining to his works. The two Kanons are complementary to each other in that they divide the letters of the alphabet between them, so that one has to go constantly from one Kanon to the other in order to complete the series. Kanon A covers in this order letters $\varepsilon$ (Odes 1 and partly 3), $\zeta, \eta(0.3), \beta(0.4), \gamma(0.5), \iota$ (and $\beta$ again) (O. 6), $x, \lambda, \mu($ O. 7), $\pi, \varrho, \sigma(O .8)$ and $\omega($ O. 9), while B covers $\alpha(O .1$ and 3$), \gamma, \delta$ (O. 4), $\varepsilon(O .5), \eta(O .6), \theta, \iota(O .7), v, \xi$, o (O. 8), $\tau, v, \phi, \chi$ and $\psi(O .9)$. This means that all the letters of the alphabet are covered once except $\gamma, \varepsilon, \eta$ and $\iota$ which appear in both poems. Such a situation entails the hand of a single author who envisages the two works as parts of the same whole and precludes the possibility of other kanons eventually belonging to the same group. On the other hand, one notices that in the first half of Kanon A the alphabetical order is somewhat perturbed, since $\varepsilon$ to $\eta$ come before $\beta$ and $\gamma$, while $\beta$ appears again a little later in the same Kanon. ${ }^{28}$

The second structural principle of the Kanons is the antistoichical one applied within each letter group. On the one hand, each consonant (or combination of consonants) is followed by the antistoicha, which tend to appear in their traditional order, i.e. $\varepsilon, \iota, o, v$. Presenting o / $v$ and $\iota$ separately is an indication of the burden of tradition on the teachers of grammar, since ou and $v$ were already pronounced as /i/ by Nicetas' time. On the other hand, each letter group concerning a vowel deals with the phonemes the written form of which consists of, starts, or occasionally ends with the vowel in question, as well as with the respective antistoicha. For example, in Al and 2, under epsilon we get $\varepsilon \mathrm{\iota} / \mathrm{\iota} / \eta$, as well as $\varepsilon$ on its own, and its

${ }^{28}$ Schneider, La poésie didactique 395 rightly speaks of the "disposition alphabétique" of the Kanons; but he does not go into further detail, apart from stating that there is no overlap between the rules of the two Kanons. Furthermore, he suggests that perhaps Kanon B was added to the collection of Nicetas' hymnic poems, the so-called חóvqua, at a later stage, see La poésie didactique 418. The way, however, the two Kanons share the letters of the alphabet seems to preclude a second edition. 
antistoichon $\alpha$. Likewise, in B1, under alpha we get the antistoicha $\alpha \mathbf{l} / \varepsilon$ (plus consonant or vowel). Judging, however, from the order of cod. Vindobonensis phil. gr. 154, this principle is not a strict one, as occasionally troparia on irrelevant letters make their appearance.

It is noteworthy that in principle this double order, alphabetical and antistoichical, is not peculiar to Nicetas. It has, for example, been applied, though in a different manner, in a form of epimerisms falsely attributed to Herodian, the principles of which are described by the unknown author himself. ${ }^{29}$

Furthermore, one can also discern a tendency to deal first with the opening syllable(s) of the words, then occasionally with the middle of a word, and finally with the end-syllables. As for the order masculine, feminine, neutral nouns, verbs and adverbs, that is characteristic of the part

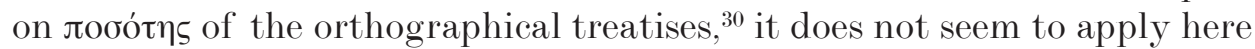
as far as the contents of each letter group are concerned, though separate troparia on adverbs do appear, sometimes at the end of a section. Nevertheless, these parts of speech form the mainstay of Nicetas' examples, while he also deals with prepositions.

Finally, let it also be mentioned that sometimes special groups of words are dealt with in a separate troparion, for instance Hebrew names (e.g. A1.18), ancient names of the months (B7.18), or names of pagan feasts (B7.21). Nicetas has an expressed interest in some of these groups in other verses of his as well, for example names of stones, which are common to both the Kanons (B7.20) and the respective verses published by Cohn (Rhythmi de lapidum nominibus). ${ }^{31}$

The future critical edition will lay the groundwork for judging yet another aspect of the poems, that of the extent of Nicetas' ability to produce metrically sound verses, and for coming up with the definitive metrical patterns he used. For the time being, the specimen produced by Cohn on the basis of three manuscripts can serve as a rough guide. Cohn separates the troparia by using double dots and dashes (:-), and the verses of each

29 Ed. J. F. Boissonade, Herodiani Partitiones. London 1819; repr. Amsterdam 1963, Iff., 157ff.; cf. Wendel, Orthographie 1451f. with bibliography; also Alpers, Theognostos 31f.; Hunger, Literatur II, 23f.; Schnemer, Les Traités 467ff. and 526ff. (on the antistoicharium of cod. Vaticanus gr. 23). See also Schneider, ibid., 584, 743 and La poésie didactique 395, who mentions two other comparable works, the xavóveऽ of cod. Vindobonensis phil. gr. 321 and the lexicon of cod. Vindobonensis phil. gr. 322.

${ }^{30}$ See Alpers, Theognostos 13.

${ }^{31}$ Rhythmi 660f. All the names of stones in this troparion appear in the respective Rhythmi (but not vice versa). 
troparion by vertical lines; however, since the text is printed as prose, the layout of a kanon as poetry is lost. But there are other more important points which show that Cohn's text is in need of correction. I will point out some of these problems, which can be solved if one takes meticulous account of the requirements of the hymnographic genre involved.

The first concerns the writing of the sounds, namely whether a letter of the alphabet in the manuscripts should be considered a letter and spelled out, or taken as a sound and not be spelled out in the edition. For example, in A1.5 Cohn writes (I follow his division of verses, though he makes no distinction between full and half verses with the result that the latter ap-

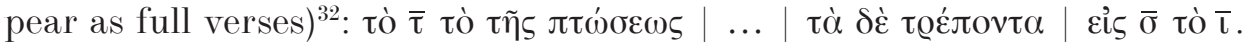
Due to the metrical and musical pattern of these verses $\left(--_{--}--\mid\right.$

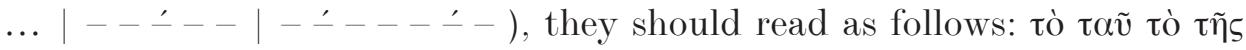

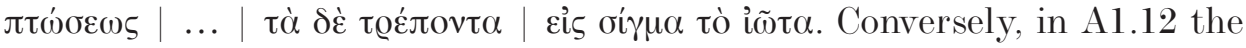

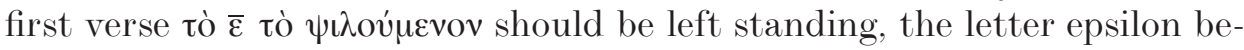
ing read as $/ \mathrm{e} /$, since the pattern of the verse is $-----_{--}$. And in A1.18

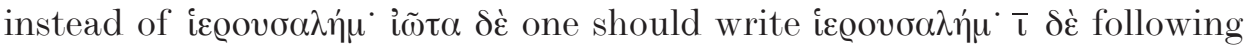
the pattern of this verse which runs as follows: $--_{--}--$(the accent on the second syllable has been affected by the difficulty to adapt the name of the city to the metre).

The second point concerns the placement of the accents. When required by the metre and if, of course, it agrees with the contents, an accent should be

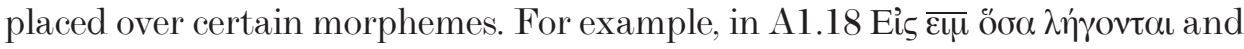

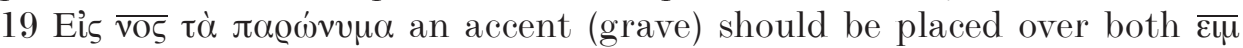
and $\overline{v_{0 S}}$, not only due to the pattern, which in both cases is $--_{--}--$, but also because the words dealt with are oxyton.

Finally, the third point concerns other corrections or possible emenda-

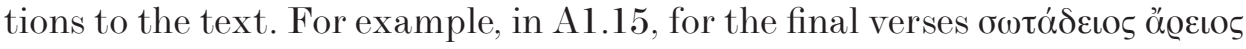
$\delta \eta \mu o \sigma \theta \varepsilon \dot{v \varepsilon l o s}$ to read correctly, a xai should be added in the last verse before $\delta \eta \mu \sigma \theta \varepsilon \dot{v \varepsilon} \iota_{0}$, in accordance with the manuscript tradition. In another case, that of A1.12, the troparion ends as follows: $\chi \omega \varrho i \check{\tilde{\omega}} v \mu \nu \eta \sigma \theta \dot{\eta} \sigma o-$

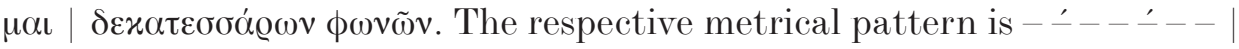
(b) - $-\dot{-}--(\dot{)})$, which means that no metrical problem seems to exist. However, only 13 words are included in the troparion that follows, where no

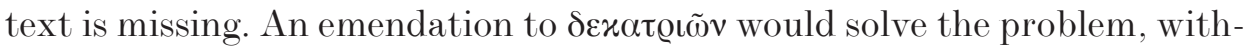
out affecting the metrical pattern in any significant way. At the same time, it turns out that the unspecified discrepancies in the last verse of the

${ }^{32}$ Cf. the respective division in the edition of the master kanon of John of Damascus in Christ - Paranikas, op. cit., 229; followed by Mitsakis, who prints troparia 12-14 of

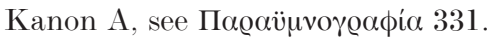


troparia of Al which, as mentioned above, were noted by Cohn were due not to Nicetas' errors and inability to produce correct verses, but to a certain degree of regulated freedom allowed by the genre.

The reasons for Nicetas' choice of the kanon form for these grammatical poems were mainly practical. Many scholars have recognized that this was a mnemotechnical device of educational character, whereby Nicetas helped his students learn correct spelling. ${ }^{33}$ In this way, the subjectmatter to be learned appealed better to the students, who knew how to sing these popular ecclesiastical melodies. This sort of work did not lack a certain snobbishness on the part of the author, as has correctly been pointed out, ${ }^{34}$ since in this way he demonstrated both his knowledge of the hymnic form involved and his abilities as a composer of such hymns. Nicetas was not alone in his choice, since a few other orthographical kanons exist under various names. ${ }^{35}$ Moreover, he applied the same device in several shorter didactic poems as well, which were inspired by other hymnic forms, such as exaposteilaria and stichera. ${ }^{36}$

In the Kanons Nicetas addresses a certain man (A3.13 $\tilde{\omega} \tau \tilde{\alpha} v ; B 7.27 ; 8.6$

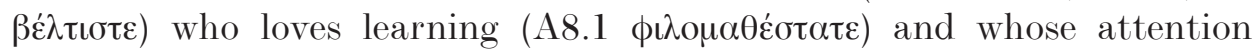

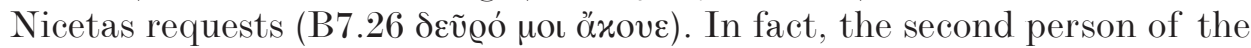

${ }^{33}$ See Egenolff, Die orthographischen Stücke 27; Darrouż̀s, Notes 182; Mitsakis,

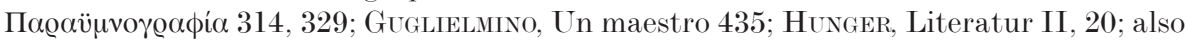
A. Tovar, Nicetas of Heraclea and Byzantine Grammatical Doctrine, in: Classical Studies presented to B. E. Perry. Urbana, Ill. 1969, 223-235, esp. 228 with reference to another grammatical poem of Nicetas; Schneider, La poésie didactique 418, 420.

${ }^{34}$ Hunger, Literatur II, 20, where he also suggests that no desecration was involved, as revealed by secular kanons of medical subjectmatter, which appear even more bizarre. Indeed, parahymnography of various content flourished from the eleventh century

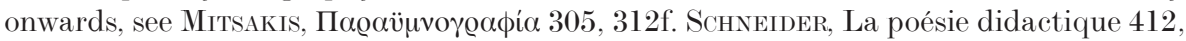
418f. argues that what he interprets as the apologetic character of the colophon of Kanon B based on the notion of the Kanons as a serious game suggests that Nicetas was concerned about a possible or real indignation on the part of some religious extremists. However, there is no indication whatsoever of such a reaction among Nicetas' contemporaries. Furthermore, for parallels to the notion of the "serious game" see W. Hörandner, Autor oder Genus? Diskussionsbeiträge zur "Prodromischen Frage" aus gegebenem Anlaß. BSl 54 (1993) 314-324, esp. 320f.; also below, pp. $182 \mathrm{f}$.

35 See, for example, the kanon under the name of Theodore (Ptocho-)Prodromos published by A. Pappadopoulos - É. Miller, Notice et collation d'un manuscrit grec de la bibliothèque de Smyrne contenant des lexiques grecs. Annuaire de l'Association pour l'encouragement des Études grecques en France 10 (1876) 121-136, esp. 131-134; cf. HuN-

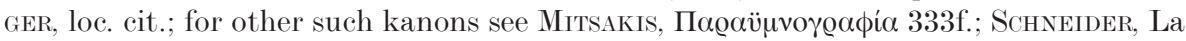
poésie didactique 419 .

36 See the lists of these shorter poems in Roosen, Works 121-124, and Schneider, La poésie didactique 389-393. 
imperative, and to a lesser extent the indicative, subjunctive and optative,

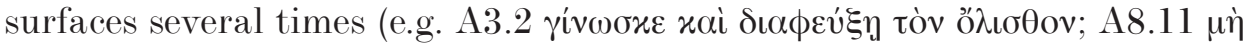

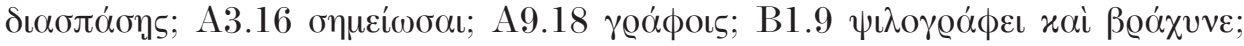

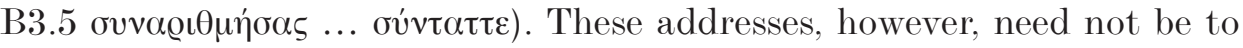
a specific person but are of a rather generic character including each one of his actual or potential students. ${ }^{37}$

The person of the author too is present throughout the Kanons not only in the form of the personal pronoun (e.g. A1.3 $\mathrm{or}$ ), but also in the first person of a verb denoting the author's consciousness of the structure

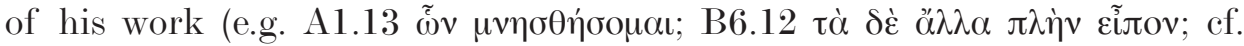

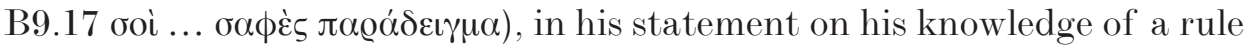

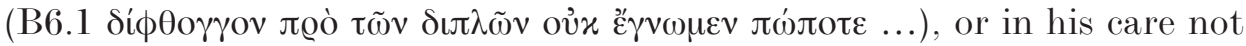

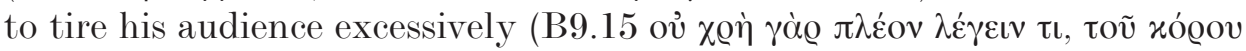

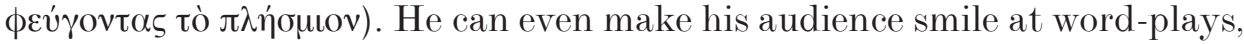
as when he says of $\pi \varepsilon v \iota$ Qós that the short /e/ is due to the reverence of the

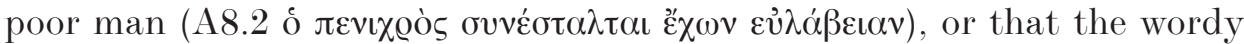

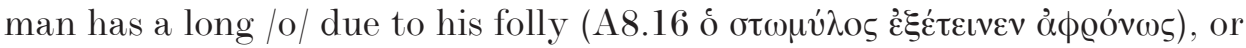
even that whoever is a really wise man (бoфós) will not approve of pomp

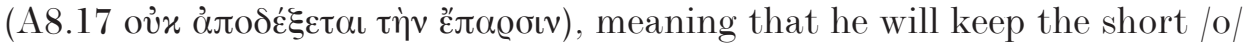
in the first syllable. ${ }^{38}$

In the colophons the author himself speaks of the character of his

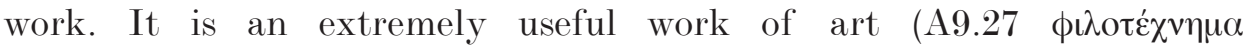

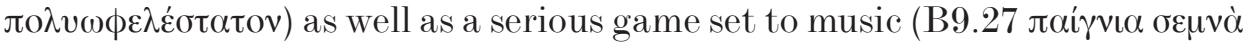
... $\mu \varepsilon \tau \dot{\alpha} \mu \dot{\varepsilon} \lambda o v \varsigma$ ), for, he notes, it is possible to play with moderation (ibid.

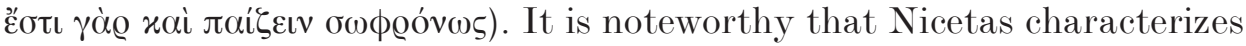
another grammatical poem of his, this time in political verses (with a

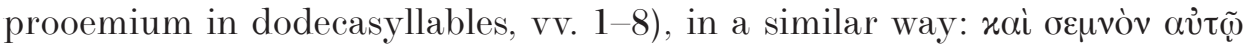

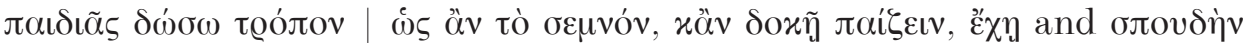

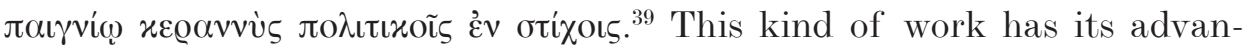

${ }^{37}$ See also SchneIder, La poésie didactique 409-411 on the audience of Nicetas' didactic poems in general.

38 On Nicetas' tendency to transform traditional grammatical language see now the extensive account by SchneIder, La poésie didactique 405-409 and 420f.: the Kanons as a sort of theatre, where the words and the object to which they refer have the same physical and moral characteristics; cf. also SchneIder, Les Traités 604f.

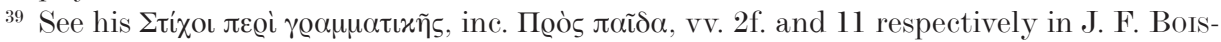
sonade, Anecdota Graeca e codicibus Regiis II. Paris 1830, 340-393. Cf. also his poem

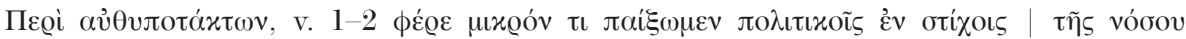

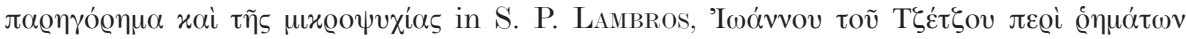

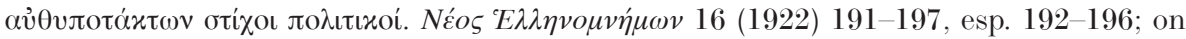
the attribution to Nicetas see Roosen, Works 127 with bibliography. See also above, p. 181 n. 34. 
tages for the author as well, as Nicetas himself admits in the latter poem, perhaps not without some exaggeration: it allowed him to write 1079 verses in just one night, a task which at the same time amused him. ${ }^{40}$ The composition of the Kanons overnight is out of the question due to the metrical complexity of the work. However, it appears that work at night appealed to Nicetas, as is also testified by another grammatical poem of his. ${ }^{41}$ As for the ease and amusement of the author, these advantages would have certainly applied to the writing of the Kanons as well. Furthermore, even though Nicetas' only desire as a reward is the audience's prayer for the salvation of his soul (B9.27), he is convinced of the fame that his work will acquire: it will be called a best-seller ${ }^{42}$ for literary men (A9.29; cf. B9.27).

Nicetas was right in his belief that his work served certain needs of both his contemporaries and posterity. As was already pointed out by Egenolff, the large number of manuscripts containing the Kanons is a testimony to their popularity. ${ }^{43}$ Egenolff himself listed seven new codices of the Kanons ${ }^{44}$ in addition, on the one hand, to the ten codices of Nicetas' XII deorum Epitheta previously identified by Studemund, ${ }^{45}$ most of which contain the Kanons as well, and on the other, to two more codices of the Kanons added by Cohn. ${ }^{46}$ Subsequently, a list of 21 manuscripts containing Nicetas" "grammatical-lexicographical" poems was presented by Sickenberger in 1902. ${ }^{47}$ Another such list of 25 codices of Nicetas' grammatical poems in general (again with no distinction as to the Kanons) was compiled "exempli gratia" by Sajdak in 1914. Most recently an almost complete

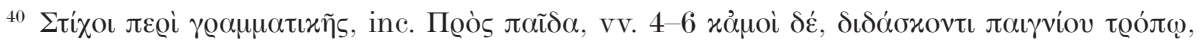

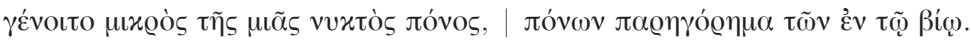

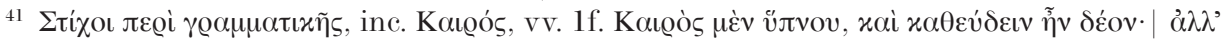

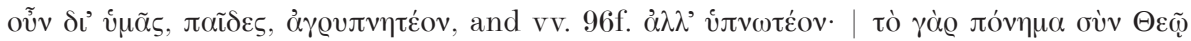

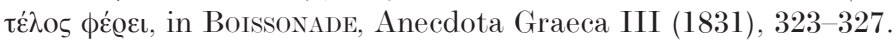

42 The word used is $\mu \varepsilon \gamma \alpha \lambda \varepsilon \mu \pi$ ogi $\alpha$, which is not found in the dictionaries of LIDDELL - SCOTT - Jones, Lampe, Sophocles, Du Cange, Stephanus, Demetrakos, or Kriaras; cf. $\mu \varepsilon \gamma \alpha \lambda \varepsilon \dot{\mu} \operatorname{cogo5}$. SchneIDER, on the other hand, translates "une aubaine (ou une cargaison?) pour les philologues", see his La poésie didactique 412.

43 Die orthographischen Stücke 28.

44 Ibid.

45 See G. Studenund, Anecdota Varia graeca musica metrica grammatica. Berlin 1886, $271-274$.

46 Rhythmi, esp. 654f. and 661.

47 Die Lukaskatene $16 \mathrm{f}$.

48 See I. SAJDAK, Historia critica scholiastarum et commentatorum Gregorii Nazianzeni (Meletemata Patristica 1). Cracow 1914, 175f., 304; a few corrections to this list by Roosen, Works 120 n. 5. R. E. Sinkewicz, Manuscript Listings for the Authors of the 
manuscript list of the Kanons was published by Schneider within a more extended list of Nicetas' so-called "hymnographic poems". It identifies (though no date is given) 27 manuscripts of the Kanons, of which 15 were examined in situ or from microfilms. ${ }^{49}$ To these I would like to add one more manuscript, Sinaiticus gr. 1204. ${ }^{50}$ Having personally examined all of the relevant manuscripts in situ or from microfilms (apart from the Cadomensis, of which no microfilm was available so far), the codices of the Kanons with the relevant folios are the following (the series in which the poems appear is indicated in parenthesis; the dates of the codices, where available, derive from published catalogues and related descriptions):

Alexandrinus 364 (-), ff. 211r-227v, 234r-242v (A, B fin. mutil.)

Atheniensis Bibl. Nat. 1065 (14th c.), ff. 167v-180r (B, A)

Atheniensis Bibl. Nat. 1379 (17th c.), ff. 419r-429v (A, B)

Berolinensis gr. 181 (16th c.), ff. 162v-171r (B)

Cadomensis 446 (17th c.), pp. 3-8 (A abbreviated)

Dresdensis Da 37 (now in Moscow; 14th c. med.), ff. 446v-460v (A, B)

Dresdensis Da 41 (16th c.), ff. 125r-148r (A, B)

Flor. Laurentianus Plut. 57.26 (14th c.), ff. $92 \mathrm{r}-112 \mathrm{v}$ (B, A)

Oxon. Baroccianus 68 (15th c.), ff. $86 \mathrm{v}-94 \mathrm{v}$ (A)

Parisinus gr. 2090 (16th c.), ff. 101v-108v (B mutil.)

Parisinus gr. 2408 (13th c.), ff. 200r-207r (A, B)

Parisinus gr. 2558 (15th c. in.), ff. 57r-72r (B, A)

Parisinus gr. 2599 (16th c.), ff. 206r-232r (A, B)

Parisinus gr. 2601 (16th c.), ff. 11v-21v (A fin. mutil.)

Parisinus gr. 2617 (14th c.), ff. 178v-183r (B)

Patmiacus 110 (13th c.), ff. $164 \mathrm{v}-182 \mathrm{v}$ (A, B)

Patmiacus 322 (14th c.), ff. $233 \mathrm{v}-247 \mathrm{v}$ (B, A fin. mutil.)

Rom. Vallicellianus B 99 (15th c.), ff. 70r-101r (A, B)

Sinaiticus gr. 1204 (15th-16th c.), ff. 300r-316r (B)

Vaticanus gr. 868 (14th c. in.), ff. $250 \mathrm{v}-264 \mathrm{v}$ (A, B)

Vaticanus gr. 873 (Pars II, 15th c. in.), ff. 278v-290v (A, B)

Vaticanus gr. 875 (13th c. ex.), ff. 298r-312r (A, B)

Vaticanus gr. 1341 (13th-14th c.), ff. 186r-200r (B, A)

Vaticanus gr. 1584 (15th c. med.), ff. 123r-143r (A, B)

Vindobonensis phil. gr. 154 (14th c.), ff. $352 \mathrm{v}-367 \mathrm{v}$ (A, B)

Patristic and Byzantine Periods (Greek Index Project Series 4). Toronto 1992 gives manuscript lists for each of the works of a certain author; unfortunately, no separate heading for the Kanons is provided.

49 La poésie didactique 398-404; the list is also published as part of the author's survey of the manuscripts of Byzantine orthographical works, see Schneider, Les traités $875-902$.

${ }^{50}$ On this codex see M. Naoumides, The Shorter Version of Pseudo-Zonaras, Lexicon, in: Serta Turyniana. Studies in Greek Literature and Palaeography in honor of Alexander Turyn. Urbana-Chicago-London 1974, 436-488, esp. 439. 
Vindobonensis phil. gr. 254 (13th c.), ff. 136r-139v (B fin. mutil.)

Vindobonensis phil. gr. 323 (13th c., 2nd half), ff. $5 \mathrm{r}-34 \mathrm{r}$ (B, A)

Vindobonensis theol. gr. 203 (14th c. med.), ff. 51r-76v (A init. mutil., B)

It becomes obvious from this list that in their present state the manuscripts usually contain both Kanons, while eight contain one or the other.

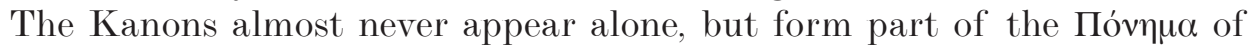
Nicetas together with a varying number of short poems of one to seven stanzas each, which, as mentioned above, are also modelled on ecclesiastical poetry. The manuscripts are almost all scholars' and teachers' books, containing mainly grammatical, lexicographical, metrical, and rhetorical works, letter collections, wise sayings, epimerisms, and schedography, as well as time calculations, and short texts of historical or religious interest. An autograph or a copy close to the date of the composition of the Kanons has not come down to us, the dates of the codices ranging from the 13th to the 17th century. On the other hand, it turns out that more than half of the manuscripts date from the Late Byzantine period, and testify to the particular popularity of the Kanons during the Palaeologan era which saw the flourishing of education. Copies continued to be produced in the postByzantine period and the Renaissance.

There are other aspects of these poems that have not been dealt with in this article, most important the problem of Nicetas' sources, ${ }^{51}$ or the drawing of a stemma codicum. ${ }^{52}$ Even so, what has been gained so far is not only an overview of the Kanons and certain suggestions relating to various problems they present, but also a brief look at the Byzantine teacher and his professional environment, as well as at the educational needs of the Byzantine class of roughly the last four centuries of the state's existence. Nicetas' texts need to be studied not only per se from the philological point of view, but also as the product of a very specific social and educational mentality that needs to be further identified and described.

51 Let it only be mentioned that for a long time the prevailing opinion was that the Kanons depend on the orthographical work of Timothy of Gaza, see WendeL, Orthographie 1453 with reference to Reitzenstein as cited by EgenolfF, Die orthographischen Stücke 34; also Krumbacher, Geschichte 587; rejected by Schneider, Les Traités 42 , 56, and esp. 70; also La poésie didactique 395 n. 46.

52 A survey of the manuscript tradition of the Kanons and the drawing of a preliminary stemma have in the meantime been the subject of a communication entitled The Orthographical Kanons of Nicetas of Heraclea and their manuscript tradition, recently delivered by the present author, see the relevant abstract in: $\mathrm{XX}^{\mathrm{e}}$ Congrès International des Études Byzantines. Pré-Actes III. Communications libres. Paris 2001, 21. 
